\title{
Characteristics of Amplang (Indonesian Traditional Snack) Fortified Rebon Shrimp (Mysis relicta) Protein Concentrate
}

Suparmi, Sumarto, Santhy Wisuda Sidauruk, Ernita Rianti

10.18805/ajdfr.DR-133

\begin{abstract}
Amplang is a typical food most known to the public in Indonesia and is a snack with low protein and high-fat content. The research was aimed to determine the effect of fortified rebon shrimp M. relicta protein concentrate on amplang processing. The parameters included the organoleptic test, proximate analysis (moisture, protein, fat, ash contents) and amino acid profile of the best treatment. From the results, the organoleptic acceptability of amplang processing revealed that $10 \%$ fortification of $M$.relicta protein concentrate $\left(\mathrm{K}_{2}\right.$ sample) in amplang processing was strongly like. The characteristics of the preferred amplang were brownish appearance: brownish (3.59), typical marine product odor (3.45), delicious flavor (3.43), and crunchy texture (2.96). Furthermore, proximate values were moisture (3.60\%), protein (11.12\%), fat (3.85\%), ash (2.00\%), and it had nine essential amino acids and eight non-essential amino acid dominated by glutamate acid (4.09\%).

Keywords: Amplang, Glutamic acid, Mysis relicta, Organoleptic, Panelist.

Asian Journal Of Dairy and Food Research (2019)
\end{abstract}

\section{INTRODUCTION}

$\mathrm{T}_{\mathrm{t} \text { to }}$ he fishery sector in Indonesia has great potential due to its archipelago topography. The role of shrimp in the exportation of fish products is significant and contributes up to $13.15 \%$. The total caught shrimps in the sea during the year 2010 amounted to 227,326 tons while the total product of shrimp cultivation in the same year was 380,972 tons (MMAF 2011).

Among the efforts to increase value and optimize the use of catchment harvests, is the development of valueadded products. The processed product diversification of fishery commodities is an alternative solution to the problem of market saturation as well as the public nutrition supply. It is necessary to develop food material processing of fishery products, leading to diversification and increase in quality foodstuff. These efforts will enhance the use and consumption of fishery products, especially in Riau (Meilin et al.2014).

Another alternative that may be considered is processing $M$. relicta into shrimp protein concentrate, a fishery product with a low water content which is generated from the mill process. In addition to the feed, $M$. relicta protein concentrate for processed food has not been used maximally. According to Fatty (2012), M. relicta powder consists of head, shell, and flesh made of calcium and phosphor. M. relicta powder, usually containing calcium and phosphor, was obtained through the process of deproteination and defatting.

Amplang is a typical food most known to the public in Indonesia. It is nearly similar to the cracker, the only difference being in the form and manner of processing. Unlike the other ones, amplang is processed without steaming. According to Howard et al., (2009), the cracker is the preferred snack that is popular among the people because it tastes interesting, delicious, and crispy. Izci and Bilgin (2015) stated that cracker $\overline{\text { Faculty of Fisheries and Marine Science, Universitas Riau, Pekanbaru }}$ Riau, 28293, Indonesia

Corresponding Author: Suparmi, Faculty of Fisheries and Marine Science, Universitas Riau, Pekanbaru Riau, 28293, Indonesia, Email: teten_58@yahoo.co.id

How to cite this article: Suparmi, Sumarto, Sidauruk, S.W. and Rianti, E. (2019). Characteristics of Amplang (Indonesian Traditional Snack) Fortified Rebon Shrimp (Mysis relicta) Protein Concentrate. Asian Journal Of Dairy and Food Research, 38(3): 247-251.

Source of support: Nil.

Conflict of interest: None

Submitted:28-06-2019 Accepted:26-09-2019 Published: 18-10-2019

in Turkey is one type of food consumed by every age group ranging from 7-70 years, most widely spread on the market and consumed ready to eat.

Amplang is a snack with low protein and high-fat contents, often perceived as a low-value product. To overcome the limitation, other materials with high protein value are added to it during processing. The amplang processed using fortified $M$. relicta protein concentrate could be expected to be very nutritious.

\section{Materials AND Methods}

The basic materials used in this study were M. relicta products, processed into Shrimp Protein Concentrate, $\mathrm{NaHCO}_{3}$ (Sigma Aldrich, Germany), and isopropyl alcohol (IPA). The formulation to make enhanced amplang is shown in Table 1.

\section{Processing of $M$. relicta amplang}

Generally, the processing of amplang uses raw material of sago powder, water, and shrimp. Other materials added 
include sugar, salt, garlic, flavor, and baking powder. The procedures followed when processing amplang using fortified M. relicta protein concentrate was as follows:

\section{Batter Process}

- M. relicta protein concentrate was weighed pursuant to the treatment of $5 \%\left(\mathrm{~K}_{1}\right), 10 \%\left(\mathrm{~K}_{2}\right), 15 \%\left(\mathrm{~K}_{3}\right)$

- Materials such as sago powder, garlic, salt, sugar, pepper, and baking soda were weighed and mixed in the tray.

- Eggs were homogenated, then added by shrimp protein concentrate.

\section{Molding}

Lustered batter was shaped long round, then cut in little finger pieces or $1 \mathrm{~cm}$ length using the powdered knife to prevent it from being too sticky.

\section{Frying}

Batters shaped in the standard size of amplang were put in cold cooking oil, fried at different fire intensities. During frying, amplang had to be stirred continuously to ensure they cooked evenly.

\section{Organoleptic test}

The products were evaluated for organoleptic test attributes using the Hedonic scale (1-9) by 80 panelists (IEC 2006).

\section{Nutritional value}

The nutritional value of the product was carried out to determine the proximate value of moisture, protein, fat, and ash content (AOAC 2005).

\section{Amino acid profile}

The analysis of amino acid was carried out to know the amino acid profile in the best treatment of amplang products. The amino acid was analyzed using high-performance liquid chromatography (HPLC) (AOAC 2005).

\section{Statistical analysis}

Data were analyzed by one-way analysis of variance (ANOVA) using SPSS Software Version 22. The research method was conducted experimentally using completely randomized design (CRD). The treatment used was the fortification of $M$. relicta protein concentrate with different concentrations $(0 \%, 5 \%, 10 \%$, and $15 \%)$. The test parameters were analyzed hedonic test, proximate, and amino acid.

\section{Results and discussion}

\section{Organoleptic Value}

\section{Appearance}

Table 2 shows that the highest mean value of amplang was in treatment $\mathrm{K}_{2}$, which is, the addition of $10 \% \mathrm{M}$. relicta protein concentrate with an average of 3.59. This was because the panelists preferred appearance criterion as brownish with spots surface of the chip. The reason for browning was due to non-enzymatic browning reactions from protein and carbohydrate generated from the raw materials of amplang processing, $M$. relicta protein concentrate. Protein content found in chips also affected the intensity of the browning reaction. According to Zzaman et al., (2016), brownish color on a fish cracker is the result of the reaction of proteins and carbohydrates undergoing Maillard reaction. The frying process affects the increase in the color of the crackers.

\section{Odor}

From Table 2, the highest value for amplang odor was found in treatment $\mathrm{K}_{2}, 3.45$, with the addition of $10 \% \mathrm{M}$. relicta protein concentrate while the lowest was seen in $\mathrm{K}_{0}, 2.57$. According to Wichaphon et al., (2013), increased shrimp odor occurred due to the presence of odor-active compounds such as trimethylamine and methional as well as volatile basenitrogen compounds. The formation of these compounds

Table 1: Formulation of amplang using fortified protein concentrate

\begin{tabular}{lllll}
\hline Material & $K_{0}$ & $K_{1}$ & $K_{2}$ & $K_{3}$ \\
\hline M. relicta Protein Concentration (g) & - & 5 & 10 & 15 \\
Sago powder (g) & 500 & 495 & 490 & 485 \\
Pepper (g) & 6 & 6 & 6 & 6 \\
Garlic (g) & 50 & 50 & 50 & 50 \\
Salt (g) & 40 & 40 & 40 & 40 \\
Egg & 2 & 2 & 2 & 2 \\
\hline
\end{tabular}

Table 2: Organoleptic test of amplang with fortified M. relicta protein concentrate

\begin{tabular}{|c|c|c|c|c|}
\hline \multirow[b]{2}{*}{ Organoleptic } & \multicolumn{4}{|l|}{ Treatment } \\
\hline & $K_{0}$ & $K_{1}$ & $K_{2}$ & $K_{3}$ \\
\hline Appearance & $3.12 \pm 0.07^{a}$ & $3.30 \pm 0.03^{a}$ & $3.59 \pm 0.17^{b}$ & $3.25 \pm 0.11^{\mathrm{a}}$ \\
\hline Odor & $2.57 \pm 0.08^{a}$ & $3.09 \pm 0.29^{b}$ & $3.45 \pm 0.06^{c}$ & $3.15 \pm 0.05^{b}$ \\
\hline Flavor & $2.90 \pm 0.11^{\mathrm{a}}$ & $3.20 \pm 0.07^{b}$ & $3.43 \pm 0.13^{b}$ & $2.88 \pm 0.08^{\mathrm{a}}$ \\
\hline Texture & $3.55 \pm 0.06^{c}$ & $3.15 \pm 0.04^{b}$ & $2.96 \pm 0.18^{a}$ & $2.86 \pm 0.09^{a}$ \\
\hline
\end{tabular}

$a, b, c$ Different superscripts indicate diffirences $(p<0.05)$ among formulations, data point are mean \pm standard deviation $(n=3)$ 
occurred due to the decomposition of various nitrogencontaining compounds, namely amino acids and amines.

\section{Flavor}

As indicated in Table 2, the highest mean value of amplang flavor with added $M$. relicta protein concentrate was in treatment $\mathrm{K}_{2}$ was 3.43 . The lowest value was in treatment $\mathrm{K}_{3}$ with 2.88. The flavor of amplang in treatment $\mathrm{K}_{2}$ was preferred by panelists because it was more delicious with typical flavor of $M$. relicta protein concentrate and others such as salt and garlic than other treatments. Garlic is categorized into taste affirmer or materials increasing chip deliciousness. In addition, foodstuff taste is derived from the material alone, and if processed, its taste would be affected by materials added during the process. According to Akonor et al., (2016), the flavor is the key component in the organoleptic assessment and an important main attribute that influences the level of consumer's acceptance of almost every food product. The flavor of fish crackers is influenced by the ratio of tapioca flour and fish. Tongdang et al., (2008) stated that the level of consumer's acceptance of the appearance and flavor of chips depends on the process of frying chips.

\section{Texture}

Fortified $M$. relicta protein concentrate had the highest value in treatment $\mathrm{K}_{0}$ with 3.55 , while $\mathrm{K}_{3}$ was the lowest at 2.86. The texture of amplang in $\mathrm{K}_{0}$ was preferred by panelists because it had a crispier texture than treatments $\mathrm{K}_{1}, \mathrm{~K}_{2}$, and $\mathrm{K}_{3}$. The addition of $M$. relicta protein concentrate and processing of amplang made starch granule ability of sago powder to bind water to reduce. As a result, in the process of amplang frying, air cavities reduced, and therefore the chips could not be crispy. The heating process would make amylopectin gelatinize, hence the elastic structure would be formed and inflate in the phase of frying. When the expansion was higher, the chip was crispier. According to Akonor et al., (2016), the texture of fried snacks is one of the important attributes with the most preferred category being crispy and crackly. The crispiness is an indicator of the quality of crackers related to the total amylopectin content of flour or starch used. Excessive use of protein will inhibit expansion through its interaction with starch granules, which results in a decrease in the crispiness of crackers.

Table 3 showed the average value of amplang with fortified $M$. relicta protein concentrate based on the level of consumer acceptance. The addition of $10 \% \mathrm{M}$. relicta protein concentrate $\left(\mathrm{K}_{2}\right)$ on amplang processing was "strongly liked" by $43.7 \%$ ( 35 panelists) consumers as compared to "like" by $51.52 \%$ (41 panelists).

\section{Nutritional Value}

The nutritional value components not only determine shelflife and nutritional quality but also determine end-use in the development of designer foods for the specific purpose (Verma and Singh 2017).

\section{Moisture content}

From Table 4, the mean value of moisture content in amplang with fortified $M$. relicta protein concentrate was highest in treatment $\mathrm{K}_{0}, 4.18 \%$, and lowest in $\mathrm{K}_{3}, 3.14 \%$. The lower moisture content was attributed to the use of $M$. relicta protein concentrate. It had low water content value since it passed through the sieving process. When compared to the standard quality of fish chips of the International Electrotechnical Commission, the maximum moisture content should be $4 \%$. Therefore, chip moisture content generated in treatments $\mathrm{K}_{0}, \mathrm{~K}_{1}, \mathrm{~K}_{2}$, and $\mathrm{K}_{3}$ met the requirements of the International Electrotechnical Commission. According to Ahmed and Abozed (2015), the moisture content of crackers is a parameter to determine the storability of the products. Low moisture content will extend the shelf life of the product. Furthermore, Mohamed et al., (1988) stated that excessive moisture content would reduce linear expansion so that the crispiness of crackers decreases.

Table 3: Consumer's acceptance of amplang with fortified $M$. relicta protein concentrate

\begin{tabular}{|c|c|c|c|c|c|c|c|c|}
\hline \multirow[b]{3}{*}{ Criteria } & \multicolumn{8}{|c|}{ Treatment } \\
\hline & \multicolumn{2}{|l|}{$K_{0}$} & \multicolumn{2}{|l|}{$K_{1}$} & \multicolumn{2}{|l|}{$K_{2}$} & \multicolumn{2}{|l|}{$K_{3}$} \\
\hline & Panelist & $\%$ & Panelist & $\%$ & Panelist & $\%$ & Panelist & $\%$ \\
\hline Strongly like & 18 & 22.50 & 16 & 20.00 & 35 & 43.75 & 13 & 16.25 \\
\hline Like & 45 & 56.25 & 54 & 67.50 & 41 & 51.25 & 50 & 62.50 \\
\hline Somewhat dislike & 16 & 20.00 & 9 & 10.00 & 4 & 5.00 & 17 & 21.25 \\
\hline Dislike & 1 & 1.25 & 0 & 0.00 & 0 & 0.00 & 0 & 0.00 \\
\hline
\end{tabular}

Table 4: Proximate analysis of amplang with fortified $M$. reticta protein concentrate

\begin{tabular}{|c|c|c|c|c|}
\hline \multirow[b]{2}{*}{ Analysis } & \multicolumn{4}{|l|}{ Treatment } \\
\hline & $K_{0}$ & $K_{1}$ & $K_{2}$ & $K_{3}$ \\
\hline Moisture & $4.18 \pm 0.08^{c}$ & $3.80 \pm 0.22^{b}$ & $3.60 \pm 0.23^{b}$ & $3.14 \pm 0.08^{a}$ \\
\hline Protein & $7.40 \pm 0.72^{\mathrm{a}}$ & $9.11 \pm 0.61^{b}$ & $11.12 \pm 0.63^{c}$ & $13.96 \pm 0.29^{c}$ \\
\hline Fat & $2.66 \pm 0.26^{a}$ & $3.10 \pm 0.06^{a}$ & $3.85 \pm 0.66^{\mathrm{b}}$ & $4.86 \pm 0.22^{c}$ \\
\hline Ash & $3.46 \pm 0.48^{c}$ & $2.08 \pm 0.42^{b}$ & $2.00 \pm 0.26^{b}$ & $1.38 \pm 0.56^{\mathrm{a}}$ \\
\hline
\end{tabular}

\footnotetext{
$a, b, c$ Different superscripts indicate diffirences $(p<0.05)$ among formulations, data point are mean \pm standard deviation $(n=3)$
} 


\section{Protein content}

From Table 4, the mean value of the protein content in amplang with fortified $M$. relicta protein concentrate was highest in treatment $\mathrm{K}_{3}(13.96 \%)$ while the lowest was in $\mathrm{K}_{0}$ (7.40\%). The protein content in amplang increased more with the addition of total $M$. relicta protein concentrate and the use of sago starch. This is attributed to the fact that $M$. relicta concentrate powder had higher protein content than sago starch. In comparison to the standard quality of Indonesian National Standard fish chips (minimum protein content is $7 \%$ ), the protein content of treatments $\mathrm{K}_{0}, \mathrm{~K}_{1}, \mathrm{~K}_{2}$, and $\mathrm{K}_{3}$ had met the requirements. According to Zzaman et al., (2016), the protein content of each fish cracker is highly dependent on fish species and the ratio of fish meat to starch used. Thus, the composition of fish meat that is higher in crackers will provide a higher protein value.

\section{Fat content}

As indiacted in Table 4, the mean value of fat content of amplang with fortified $M$. relicta protein concentrate was highest in treatment $\mathrm{K}_{3}(4.86 \%)$ and lowest in $\mathrm{K}_{0}(2.66 \%)$. The fat content of amplang was in the range (5-15\%) given by the US Department of Agriculture for the crude fat content of crackers. The fat content contributes greatly to the total calories of a diet, so lower fat content in crackers is safer for patients who are health conscious and anorexic (Owusu et al., 2011). The value of fat content in amplang has increased with an increase in the addition of $M$. relicta protein concentrate. According to Kolade et al., (2014), the frying process can increase the fat content of shrimp crackers, owing to the release of water into pure vegetable oil, thereby leading to low moisture content.

\section{Ash content}

From Table 4, the highest mean value of ash content in amplang with fortified $M$. relicta protein concentrate was seen in treatment $\mathrm{K}_{1}(3.46 \%)$ while the lowest was seen in $\mathrm{K}_{3}$ (1.38\%). According to Pomeranz and Meloan (1987); Haard (1996), the ash content includes the elements magnesium, calcium, iron, and manganese in the mineral material.

A significant difference $(p<0.05)$ was found for all sensory attributes and nutritive value between control and fortified $M$. relicta protein concentrate and the follow-up test conducted by Tukey's HSD test.

\section{Amino Acid Profile of the Best Amplang Treatment}

The best amplang treatment was obtained in $\mathrm{K}_{2}(10 \%$ fortified $M$. relicta protein concentrate) based on the level of consumer acceptance. Table 5 showed that Ampang with $10 \%$ fortified $M$. relicta protein concentrate $\left(\mathrm{K}_{2}\right)$ had nine essential amino acids consisting of histidine, arginine, threonine, valine, methionine, isoleucine, leucine, phenylalanine, and lysine. Eight non-essential amino acids were detected in $\mathrm{K}_{2}$, namely aspartic acid, glutamic acid, serine, glycine, alanine, proline, tyrosine, and cysteine. Ampang chips contained the most amino acids influenced by fortified $M$. relicta protein concentrate. Jacoeb et al., (2008) stated that shrimp Harpiosquilla raphidea muscle protein consisted of 17 amino acids, nine essential amino acids, and eight non-essential amino acids hence, that Shrimp Harpiosquilla raphidea muscle can be said to have a complete protein profile.

Glutamic acid is the highest non-essential amino acid contained in the Amplang with a $10 \%$ fortified M. relicta protein concentrate of $4.09 \%$. Jacoeb et al. (2008) stated that shrimp contains high glutamic acid. According to Heu et al. (2003), glutamic acid and aspartic acid were the most influential on taste.

\section{Conclusions}

The addition of $M$. relicta protein concentrate to amplang processing had a significant effect on the organoleptic test (appearance, odor, flavor, and texture) and nutritive value (moisture, protein, fat, and ash content). This study concludes that treatment $\mathrm{K}_{2}$ with $10 \%$ fortified $M$. relicta protein concentrate was the best treatment and could be accepted by consumers, where 43.75\% "strongly like" while 51.52\% "like." The accepted product had a brownish appearance (3.59), typical marine product odor (3.45), delicious flavor (3.43), and crunchy texture (2.96). The content of chemical nutrition was consistent with the International Electrotechnical Commission for amplang with moisture (3.60\%), protein (11.12\%), fat (3.85\%), and ash (2.00\%). Amplang with $10 \%$ fortified $M$. relicta protein concentrate $\left(\mathrm{K}_{2}\right)$ had a complete protein profile dominated by glutamic acid (4.09\%). Give one or two concluding sentences.

Table 5: Amino acid profile of amplang with 10\% fortified $M$. reticta protein concentrate $\left(\mathrm{K}_{2}\right)$

\begin{tabular}{ll}
\hline Amino acid profile & $\begin{array}{l}\text { Amplang with 10\% fortified } M \\
\text { relicta protein concentrate (\%) }\end{array}$ \\
\hline Aspartic acid & 2.51 \\
Glutamic acid & 4.09 \\
Serine & 0.74 \\
Glycine & 0.56 \\
Alanine & 0.76 \\
Proline & 1.57 \\
Tyrosine & 1.02 \\
Cysteine & 0.78 \\
Histidine & 1.43 \\
Arginine & 1.52 \\
Threonine & 1.09 \\
Valine & 1.56 \\
Methionine & 1.14 \\
Isoleucine & 0.86 \\
Leucine & 2.10 \\
Phenylalanine & 1.03 \\
Lysine & 1.30 \\
\hline
\end{tabular}




\section{References}

Ahmed, Z. S. and Abozed, S. S. (2015). Functional and antioxidant properties of novel snack crackers incorporated with Hibiscus sabdariffa by-product. J.Adv. Res., 6: 79-87.

Akonor, P. T., Dziedzoave, N. T., Buckman, E. S., Essel, E. M., Lavoe, F., Tomlins, K. I. (2016). Sensory optimization of crackers developed from high-quality cassava flour, starch, and prawn powder. Food Science and Nutrition, 5: 1-6.

AOAC. (2005). Official methods of analysis of the association of official analytical chemists. The Association of Official Analytical Chemist Inc, Virginia.

Fatty, A. R. (2012). The effect of udang rebon addition to nutritional content and hedonic test result in Tempe ball (Undergraduate thesis, Indonesia University, Indonesia). Retrieved March 23, 2019, from http://www.lib.ui.ac.id/detail?id=20308442\&loka si=lokal\#parentHorizontalTab2

Haard, N. F. (1996). Characteristics of edible plant tissue in: Fennema, R. O. Karel, M.; Sandarsen, G. W.; Tannenbaum, S. R.; Walstra, P.; Witaker, J. R. Food Chemistry. Marcel Dekker Inc, New York.

Heu, M.S., Kim, J. S., Shahidi, F. (2003). Components and nutritional quality of shrimp processing by-products. Food Chem, 82: 235-242.

Howard, B. M., McWatters, K. H., Saalia, F., Hashim, I. (2009). Formulation and evaluation of snack crackers made with peanut flour. Cereal Food World, 54: 166-177.

IEC. 2006. SNI-01-2346-2006: Instructions for organoleptic and sensory testing. International Electrotechnical Commission, Indonesia.

Izci, L., and Bilgin, S. (2015). Sensory acceptability and fatty acid profile of fish crackers made from Carassius gibelio. Food Sci Tech-Brazil, 35: 643-646.

Jacoeb, A. M, Cakti, N. W., Nurjanah. (2008). Composition Alteration of Protein and Amino Acid of Ronggeng Shrimp (Harpiosquilla raphidea) Meat by Boiling. Indonesian Fisheries Processing Journal, 11: 1-20.

Kolade, O. Y., Adeyemi, Y. B., Amusan, E. E. (2014). Development, nutritional, and sensory evaluation of innovative ready to fry crackers from pink shrimp (Paneus notialis). Continental J. Food Science and Technology, 8: 16-21.

Meilin, S., Desmelati, Sumarto. (2014). An Assessment on Consumer Acceptance and Quality of Shrimp Nugget (Acetes erythraeus). BERNAS Agricultural Research Journal, 8: 55-66.

Ministry of Marine Affairs and Fisheries [MMAF]. (2011). Marine and fisheries principal data. Jakarta.

Mohamed, S., Abdullah, N., Muthu, M. K. (1988). Expansion, oil adsorption, elasticity and crunchiness of keropok (fried crisps) in relation to the physicochemical nature starch flours. In Maneepun, S., Varangoon, P. and Phithakpol, B. (Eds). Food Science and Technology in Industrial Development, Proceedings of the Food Conference' 88 , (pp. 108-113). Bangkok, Thailand: IFRPD-Kasetsart University.

Owusu, D., Oduro, I., Ellis, W. O. (2011). Development of crackers from cassava and sweet potato flours using Moringa oleifera and Ipomeae batatas leaves as fortificant. American Journal of Food and Nutrition, 1: 114-122.

Pomeranz, Y. and Meloan, C. E. (1987). Food analysis: theory and practice $\left(2^{\text {nd }}\right.$ ed). Van Nostrand Reinhold, New York.

Tongdang, T., Meenun, M., Chainui, J. (2008). Effect of sago starch addition and steaming time on making cassava cracker (Keropok). Starch-Strake, 60: 568-576.

Verma, A. and Singh, V. 2017. Formulation and quality evaluation of mushroom (Oyster mushroom) powder fortified potato pudding. Asian J. Dairy \& Food Res, 36: 72-75.

Wichaphon, J., Posri, W., Assavanig, A., Thongthai, C., Lertsiri, S. (2013). Categorization of thai fish sauce based on aroma characteristics. J. Food Quality, 36: 91-97.

Zzaman, W., Yusoff, M. M., Yang, T. A. (2016). Preparation and properties of fish cracker from different freshwater fish water. International Food Research Journal, 24: 1858-1862. 